\title{
Economic performance of benthic resource management areas in the Bío-Bío region
}

\author{
Catterina Sobenes ${ }^{1} \&$ Carlos Chávez ${ }^{2}$ \\ ${ }^{1}$ Facultad de Ingeniería, Universidad Católica de la Santísima Concepción \\ Alonso de Ribera 2850, Concepción, Chile \\ ${ }^{2}$ Departamento de Economía, Facultad de Ciencias Económicas y Administrativas \\ Universidad de Concepción, Casilla 1987, Concepción, Chile
}

\begin{abstract}
The economic performance of Benthic Resource Management Areas (BRMA's) was assessed and analyzed for the Bío-Bío region between 2001 and 2003. This study included 22 areas with Use Agreements declaring 'loco' (Concholepas concholepas) to be the main benthic resource. Several characteristics were also considered as potential determinant factors for BRMA performance. These variables were defined and grouped into four types of characteristics: economic, environmental-biological, institutional-organizational, and organizational leader. The variables were then contrasted between areas according to the loco harvest situation. Moreover, the economic performance profiles of BRMA's with loco harvests were analyzed according to the considered variables. The results indicate, beyond the different environmental-biological aspects, important differences in economic and institutional-organizational characteristics between areas with and without loco harvests during the period analyzed. Moreover, we conclude that some key variables are associated with economic performance in the areas that harvested loco during the study period, including economic (selling price) and environmental-biological (resource density, habitable polygon) variables.
\end{abstract}

Key words: managed areas, benthic resources, economic performance, loco, Concholepas concholepas, Chile.

\section{Desempeño económico de áreas de manejo de recursos bentónicos en la región del Bío-Bío}

RESUMEN. Se evaluó y analizó el desempeño económico de Áreas de Manejo de Recursos Bentónicos (BRMA) de la región del Bío-Bío durante el período 2001-2003. Con tal propósito, se consideró un total de 22 áreas con Convenio de Uso que declararon como especie principal el recurso bentónico loco (Concholepas concholepas). El análisis del desempeño económico de las BRMA's considera la exploración de diversas características como potenciales factores determinantes del referido desempeño. Específicamente, se definieron variables agrupadas en cuatro tipos de características para cada área: económicas, ambientales-biológicas, institucionales-organizacionales y características del dirigente. Las variables fueron comparadas entre las áreas de acuerdo a la situación de cosecha de loco. Se realizó también un análisis del perfil del desempeño económico de BRMA's con cosecha del recurso según las variables consideradas. Los resultados indican que, más allá de diferencias en los aspectos ambientales biológicos, existen diferencias significativas en variables económicas, y de características institucionales-organizacionales entre áreas con y sin cosecha de loco durante el periodo analizado. Adicionalmente, se concluye que existen variables claves asociadas al desempeño económico de las áreas que cosechan el recurso en el periodo; entre otras, aquellas económicas (precio de venta); y ambientales-biológicas (densidad del recurso, y polígono habitable).

Palabras clave: área de manejo, recursos bentónicos, desempeño económico, loco, Concholepas concholepas, Chile.

Corresponding author: Catterina Sobenes (e-mail:csobenes@ucsc.cl) 


\section{INTRODUCTION}

The exploitation of benthic resources by artisanal fishermen is an example of the use of common pool resources. Here, we use the term "common pool resources" to indicate the presence of rivalry and non-exclusion. Conceptually, these two key characteristics define this kind of good or resource; the first indicates the presence of rivalry over resource use between current and possible agents and the second is characterized by difficulty in excluding some agents from the resource use or exploitation. Because common pool resources generate individual incentives that are not necessarily the same as the group objectives, socially undesirable results such as overuse or overexploitation of natural resources and the lack of cooperation among agents are expected to occur in different contexts (Taylor, 1987; Ostrom \& Gardner, 1993; Ostrom, 1995).

One solution to the problem of managing common pool resources, and the focus of attention of this work, is that in which the people involved, in this case artisanal fishermen, make a limited negotiation contract, developing a cooperative strategy that they will implement. In this common pool resource management plan, the agents involved have the right to use and exploit the resource, define the organization and its operational rules, and are responsible for the management and exploitation of the resources in a determined geographical area (Taylor, 1987). This regulation system, based on the creation and designation of rights of territorial use, has been used in Chile since the last decade. In fact, Benthic Resource Management Areas (BRMA) are a measure of fishing administration (access regime) in Chile through which legally constituted artisanal fishing associations are assigned exclusive rights to use and exploit benthic resources in geographical sectors located within the five-mile coastal strip reserved for artisanal fishing or in inland and interior waters (SUBPESCA, 1995).

This measure was enacted in the 1990s in Article 48, letter (d) of the current Ley General de Pesca y Acuicultura (General Fishing and Aquaculture Law). Between 1991 and 1994, the first project for evaluating and managing benthic resources was carried out in 13 coves of the Choapa Province. The project, "Módulos de Manejo de Pesquerías Artesanales de la IV Región" (Management Modules for Artisanal Fisheries in Region IV), laid the conceptual and methodological groundwork for the current Base Situation Studies (ESBA) and
Management and Exploitation Plans (PME) of these areas. In Chile, an official request was made in 1997 for six BRMAs covering a total surface area of 2,000 ha (Jerez, 2001). By 2003, there were a total of 39 BRMAs operating in the Bío-Bío region; these were authorized to use and exploit benthic resources.

The characteristics of the BRMA regime suggest that it constitutes a suitable instrument for the conservation and rational use of benthic resources and the cooperation of artisanal fishing associations with the fishery administration. Given this, we expect the regime to permit viable artisanal economic activity through the designation of natural shoals of benthic resources (SUBPESCA, 1995). Despite the increasing importance of this innovative fishing admninistration system, no previous works have systematically evaluated this critical aspect of BRMA operations at either the national or regional (Bío-Bío) level.

In order to analyze the results of applying this exploitation regime, it is first necessary to evaluate the BRMA performance with regard to its objectives. Such an evaluation requires an indicator for the administrative measure's impact on wellbeing in the coastal area considering, for example, the coastal ecosystem including both human and nonhuman elements. Ideally, this evaluation would compare information gathered prior to the existence of the managed area (base line) with information gathered after the implementation of the BRMA. Unfortunately, base line information is generally unavailable or described with some other orientation (usually biological), making it unsuitable for these purposes and thereby preventing before-and-after comparisons in terms of the implementation of the administrative measure. Furthermore, it has been suggested that the perception of key agents with regard to the success of the differents managed areas or their performance may be a first approach to this evaluation (Pollnac et al., 2001; Sumalde \& Pedroso, 2001; Kamara et al., 2002). Alternatively, the results of the management policy could be analyzed by directly evaluating economic performance, understood as the level of economic profits per period generated by the BRMA.

The objective of this work is to describe and analyze the economic performance of BRMAs in the Bío-Bío region from 2001 to 2003. To do this, we first calculated an economic performance indicator of the BRMAs studied. Then we used a descriptive statistical analysis to explore the role of economic, environmental-biological, and institutional-organiza- 
tional factors and the characteristics of the organizational leaders as determinants for the occurrence or lack of harvesting in the period considered. Finally, a descriptive analysis of the role of the previously mentioned factors was used to define their possible incidence as determinants of the economic performance observed in the BRMAs with harvesting in the analyzed period.

An important number of published works refer to Benthic Resource Management and Exploitation Areas off Chile. Most of these associate biological and technical aspects with the operations of the managed areas (Castilla \& Fernández, 1998; Jerez, 2001). González (1996) provides an initial analysis of the administration measure, including its origins and a general description of its main aspects. Cereceda \& Czischke (2001) report on case studies that examine success factors in two coves: El Quisco and Quintay. In addition to these, a study by the Fishery Research Fund prepared by the Ecology and Resource Management Group of the Universidad Católica del Norte analyzes the performance of BRMAs according to biological indicators (see the Final Report for FIP Project 2003-18, November 2005). A recent case study describes organizational styles and operating rules in Benthic Resource Management and Exploitation Areas of the Bío-Bío Region (Palma \& Chávez, 2006).

\section{MATERIALS AND METHODS}

\section{Study area}

The study includes Benthic Resource Management and Exploitation Areas in the Bío-Bío Region with Use Agreements that declare loco (Concholepas concholepas) to be the main species harvested. A total of 22 BRMAs were considered between 2001 and 2003; of these, only 19 reported harvests. It is important to mention that the areas are currently operating and can harvest the corresponding benthic resources according to the time stipulated in the Use Agreement made between the organization and the State. Consequently, the areas begin their operations by selling their harvests and incurring different costs, for example, direct exploitation costs and those related to the elaboration of follow-up reports. Even though some BRMAs in the region have generated incomes in the indicated period through harvesting species other than loco, such activities are not relevant in the total income. For example, in its two years of operation, the Peroné area in Concepción Province has reported $91 \%$ of its total income from loco harvesting and the remaining $9 \%$ from limpet harvesting (Fissurela spp.).

\section{Data analyzed}

We gathered information from BRMA follow-up reports and harvest and price records available from the Servicio Nacional de Pesca (SERNAPESCA). This information was complemented with structured surveys to the leaders of organizations administering the areas in the period considered. The data was filtered to eliminate those areas generating atypical observations or with widely different behavior in the data as compared to the rest of the areas observed. Specifically, using the procedure described resulted in the elimination of the data from the west of the Isla Mocha, which has a surface area of 5,078 ha and much larger harvest volumes than the other studied areas.

\section{Economic performance}

The economic performance was evaluated by calculating an indicator of the net annual per capita profit from loco harvesting. This concept corresponds to the per capita quasi rent because not all the relevant fixed costs are considered. In particular, we could not considerate capital costs associated with exploitation because no suitable data were available. This variable was calculated yearly for each BRMA as the difference in the total annual income for loco harvesting minus the total costs observed, divided by the number of members in the managed area during the corresponding period. The total incomes were obtained by multipling the average annual price (deflated) of loco in each BRMA and by the total annual harvest recorded. The deflated costs include operation costs such as provisions, transportation, materials for extraction, office supplies, follow-up consulting services, unforeseen expenses and other minor costs, fuel costs, and other costs associated with equipment and engine maintenance. The prices and costs were expressed using the value of the Chilean peso in December 2001. For this, the prices and costs were deflated by an index 1 for 2001, 1.028 for 2002, and 1.039 for 2003. This index is calculated based on the Consumer Price Index (IPC) from December 2001 (IPC = 109.76), December 2002 (IPC = 112.86), and December 2003 (IPC= 114.07). Then, based on December 2001 (IPC December $2001=$ $100)$, we re-scaled the rest. By dividing the price in 
each area-year according to the respective index, this was expressed in Chilean pesos for December 2001 (a similar procedure was used for the cost information). Formally, the net income per capita for BRMA $i$ in year $t$ can be described as follows:

$$
\text { benefpc }_{i t}=\frac{p_{i t}^{*} q_{i t}-c_{i t}}{\text { socios }_{i t}}
$$

where:

benefpc $_{\text {it }}$ : is the net income per capita (in pesos) for area $i$ in year $t$,

$\mathrm{p}_{\mathrm{it}} \quad$ : is the average price of loco (in pesos/unit) in area $\mathrm{i}$ in year $\mathrm{t}$, deflated to 2001 ,

$\mathrm{q}_{\mathrm{it}} \quad$ : is the amount of loco harvested (in units) in area $i$ in year $t$,

$\mathrm{c}_{\mathrm{it}} \quad:$ is the total annual cost of the harvest (in pesos) in area $i$ in year $t$, deflated to 2001 , and

$\operatorname{socios}_{i t}$ : is the number of members in area $\mathrm{i}$ in year t.

No univocal correspondence between area and organization existed in the data used herein, so an organization could have more than one area. However, this situation is not common; specific cases of organizations with more than one area occurred with the organization managing Punta Lavapié, Punta Los Piures, Bajo Rumana, and Punta Raimenco, and the organization managing Puerto Norte A, Puerto Norte $\mathrm{B}$, and Puerto Norte $\mathrm{C}$. The analysis considered every observation independently.

The data for the total annual harvesting costs include operational costs declared by fishermen in their follow-up reports, especially in the cash flow.

The calculation of the economic performance through equation 1 did not consider the probable existence of hetereogenity among the studied BRMAs with regard to their organizational forms, production, and the designation of harvest quotas or standards for internal profit distribution. Some possible differences in the economic performance between BRMAs are related to differences in production and harvesting aspects, and the distribution of the activity's income. In this sense, it would be interesting to explore performance indicators for subgroups of artisanal fishermen that are members of these organizations according to their specialties including, for example, ship-owners, divers, diving assistants, fishing crew members, and algae collectors. However, information was not available on income distribution and ways of production organization for the areas considered. In fact, in a recent case study that considered four managed areas located in the Bío-Bío region, Palma \& Chávez (2006) suggest that, even when the studied areas present similar organizational and operational aspects, important differences remain related to the vigilance systems used as well as the rules for the distribution of the economic income among the members of the organizations.

Economic, environmental-biological, institutional-organizational, and organizational leader characteristics of the Bío-Bío region BRMAs

The analysis of the economic performance of Bío-Bío region BRMAs from 2001 to 2003 considered several characteristics as potential determinant factors of such performance. Specifically, we included the economic, environmental-biological, institutional-organizational and organizational leader characteristics. Consequently, we gathered information on the selected BRMAs and classified it as one of the following types of variables:

1) Economic characteristics:

Price of the main species $\left(\mathrm{PLOCO}_{\mathrm{it}}\right)$ : corresponded to the average price per unit of loco in pesos observed in every area i in year t. Of these characteristics, no information was available on income distribution in the different areas studied. It would be interesting to consider this variable in the future.

\section{2) Environmental-biological characteristics:}

Hectares of the area $\left(\mathrm{HAS}_{\mathrm{i}}\right)$ : number of hectares included within the coastal area borders forming a polygon; this is defined when area $i$ is requested and determined by a legal resolution.

Average size (SIZEit): average size in $\mathrm{mm}$ of the resource available for harvesting in area i in year $t$.

Commercial size fraction (FRACOMSIZEit): the percentage of specimens in the total biomass that are equal to or larger than $100 \mathrm{~mm}$ in area $\mathrm{i}$ during year $t$.

Habitable polygon (bathylogical chart) (POLIGOi): the variable describing the surface inhabited by the benthic resources in area $\mathrm{i}$. This is a continuous variable, expressed as surface in $\mathrm{m}^{2} \cdot 1000^{-1}$.

Density of other species (DENSOTHERit): density of other species presents in area $i$ during year $t$ that are interrelated within the area. It is measured in individuals per square meter (ind $\cdot \mathrm{m}^{-2}$ ). 
Density of the target species (DENSREit): individuals per square meter of the main species for extraction $\left(\right.$ ind $\cdot \mathrm{m}^{-2}$ ) in area i during year $\mathrm{t}$.

Growth parameter (BETAi): growth parameter relating an estimate of weight in function of the length of the species in area $i$.

\section{3) Institutional-organizational characteristics:}

Number of members $\left(\right.$ NMEMBERS $_{\text {it }}$ ): number of fishermen registered in the organization of area $i$ in year $\mathrm{t}$.

Number of divers (NDIVERSit): number of divers belonging to the union administering area $\mathrm{i}$ in period $\mathrm{t}$.

Type of organization: this indicates whether the organization is a labor union (UNION), trade union association (ASOCG), or another; this is a dichotomous variable, being 1 if the organization is a labor or trade union association and 0 in all other cases.

Gender (MENit): percentage of MEN members of the organization administering area $i$ during period $t$.

Organizational fee value (FEEit): the value to be contributed by every fisherman belonging to the organization administering area $\mathrm{i}$ to facilitate its management. This is a continuous variable.

Surveillance (PATROLit): this is a dichotomous variable intended to identify the presence of continuous vigilance in area $i$, being 1 if the organization has vigilance and 0 in all other cases.

Rural-urban location (URBANi): location of the area in the region; this is a dichotomous variable, being 1 if the BRMA is located in an urban zone and 0 in all other cases.

\section{4) Characteristics of the leader:}

Age (AGEit): age of the leader of area $i$ in period $t$.

Education (EDUCAit): education level of the leader of area $i$ in period $t$. This is a categorical variable on a scale of 1 to 5: incomplete elementary education (1), complete elementary education (2), incomplete secondary education (3), complete secondary education (4), higher training or other (5).

Experience in the activity (EXPFISHINGit): number of years that the leader of area i has worked in the fishing activity through period $t$.

Leadership experience $\left(\right.$ EXPLEADER $_{\mathrm{it}}$ ): number of years that the person has been the leader of the organization administering area $\mathrm{i}$ through period $\mathrm{t}$.

Other economic activity $\left(\mathrm{OTHERACT}_{\mathrm{it}}\right)$ : this indicates whether the leader of area $i$ has another work activity or not during period $t$; this is a dichotomous variable, being 1 if the leader works in another place and 0 in all other cases.

Marital status $\left(\right.$ MARRIED $\left._{\mathrm{it}}\right)$ : this indicates the marital status of the leader of the organization administering area $\mathrm{i}$ during period $\mathrm{t}$; this is a dichotomous variable, being 1 if the leader is married and 0 in all other cases.

\section{Treatment of the information}

A descriptive analysis of the information gathered was developed, and the annual per capita profit observed from 2001 to 2003 was evaluated according to each BRMA's harvest situation.

We evaluated the difference between years according to the state of the harvest, and among areas with and without harvests in order to verify whether the samples observed over time changed. This was done through a comparison test of means applied to all the variables considered for the factors included in the analysis (economic, environmental-biological, institutional-organizational and organizational leader characteristics). We verified the normality for the quantitative data through the non parametric Kolmogorov-Smirnov test, finding a significance of 5\% normality in the data analyzed (Canavos, 1992).

In order to compare the mean values between the areas with and without harvests, we first analyzed the equality of variances between both samples by contrasting the null hypothesis $H_{o}: \mathrm{S}^{2}{ }_{1}=\mathrm{S}_{2}{ }_{2}$ versus the alternative hypothesis $H_{1}: \mathrm{S}^{2}{ }_{1} \neq \mathrm{S}_{2}{ }_{2}$, where $\mathrm{S}^{2}$ is the variance of the variable observed, with $j=1.2$. For that, we used the statistical $\mathrm{F}$ test:

$$
F=\frac{\frac{1}{\left(n_{1}-1\right)} \sum_{i=1}^{n_{1}}\left(x_{i}-\bar{x}_{1}\right)}{\frac{1}{\left(n_{2}-1\right)} \sum_{i=1}^{n_{2}}\left(x_{i}-\overline{x_{2}}\right)}=\frac{S_{1}^{2}}{S_{2}^{2}}
$$

that follows Fisher's F distribution with $\left(\mathrm{n}_{1}-1\right)$ and $\left(\mathrm{n}_{2}-1\right)$ degrees of liberty (Canavos, 1992).

In a second stage, if the variables of both samples presented equal variances, we applied a comparison test among the means observed and contrasted the null hypothesis $\mathrm{H}_{\mathrm{o}}$ : versus the alternative hypothesis $\mathrm{H}_{1}$ : , where $\mu_{\mathrm{j}}$ is the sampled mean of the variable 
observed, with $j=1.2$. For this, we used the statistical test defined as:

$$
t=\frac{\left(\bar{x}_{1}-\bar{x}_{2}\right)}{S_{F} \cdot \sqrt{1 / n_{1}+1 / n_{2}}}
$$

where:

$\mathrm{n}_{1}$ and $\mathrm{n}_{2}$ : the number of observations in samples 1 and 2 , respectively,

$\mathrm{x}_{1}$ and $\mathrm{x}_{2}$ : are the sampled means for the variables observed in samples 1 and 2, respectively, and

$\mathrm{S}_{\mathrm{F}}^{2} \quad$ : is the combined estimator of the common variance $\sigma^{2}$ between the samples, given by:

$$
S_{F}^{2}=\frac{\left[\left(n_{1}-1\right) \times S_{1}^{2}+\left(n_{2}-1\right) \times S_{2}^{2}\right]}{\left(n_{1}+n_{2}-2\right)}
$$

where $\mathrm{S}^{2}$ and $\mathrm{S}_{2}^{2}$ are the sampled variances of samples 1 and 2, respectively.

This estimator distributes Student's t with 1- $\alpha$ degrees of liberty (Canavos, 1992). When it was not possible to reject the hypothesis of equality of variances between the samples, we applied Welch's test (Canavos, 1992):

$$
t=\frac{\left(\bar{x}_{1}-\bar{x}_{2}\right)}{\sqrt{\left(S_{1}^{2} / n_{1}\right)+\left(S_{2}^{2} / n_{2}\right)}}
$$

This estimator distributes Student's $t$ with $f$ degrees of liberty, where:

$$
f=\frac{\left(S_{1}^{2} / n_{1}-S_{2}^{2} / n_{2}\right)^{2}}{\frac{1}{n_{1}-1}\left(\frac{S_{1}^{2}}{n_{1}}\right)^{2}+\frac{1}{n_{2}-1}\left(\frac{S_{2}^{2}}{n_{2}}\right)^{2}}
$$

In order to evaluate whether there are significant differences between the years for all areas, we contrasted the null hypothesis $\mathrm{H}_{\mathrm{o}}$ : versus the alternative hypothesis $\mathrm{H}_{1}$ : , where is the mean of the variable observed in 2001, 2002, and 2003, with $\mathrm{m}=1,2$, and 3. In this case, an analysis of variance of one factor was carried out whose null hypothesis was rejected when the value of the F statistic was found within a critical region greater than size $\alpha$, which was evaluated as:

$$
F=\frac{\sum_{m=1}^{3} \sum_{i=1}^{n_{j}}\left(\bar{x}_{\cdot m}-\bar{x}\right)^{2} /(k-1)}{\sum_{m=1}^{3} \sum_{i=1}^{n_{j}}\left(x_{i m}-\bar{x}_{\cdot m}\right)^{2} /(N-k)}
$$

whose Fisher's F distribution had a significance of $1-\alpha$, and the pair k-1, N-k degrees of liberty (Canavos, 1992).

Finally, in order to descriptively evaluate possible relationships between economic, environmentalbiological, institutional-organizational and organizational leader characteristics and the per capita profit, a graphical analysis among such variables was carried out.

\section{RESULTS}

\section{Evaluated benthic resource managed areas}

The BRMAs shown in Table 1 were analyzed considering the selection criterion of the areas. The situation of the managed area was identified to see if it reported positive or negative loco harvests. Aditionally, we considered the condition of the observed per capita profit, be it positive, zero, or negative.

The previous table shows a total of 8,17 , and 21 analyzed areas for 2001, 2002, and 2003, respectively. It is interesting to point out that a number of areas with Use Agreements do not report any harvests during the study period. This could have two causes. First, the areas do not harvest because they are waiting to recover the abundance levels of the target species and/or have not been authorized by SERNAPESCA. Second, fishing organizations do not harvest due to internal management problems, including definition of rules or operational standards and financial problems such as no working capital or other managerial problems. In this study, the main cause reported for not harvesting per area was not identified; only the harvest condition was determined.

\section{Descriptive analysis of the economic performance}

We carried out a descriptive analysis of the variables observed in the group of managed areas with loco harvests and another for the group of managed areas without loco harvests, comparing the variables between the two groups. 
Table 1. BRMA under agreement of use in the Bío-Bío region between 2001-2003 according to harvest condition and level of profit per capita.

\begin{tabular}{|c|c|c|c|}
\hline & 2001 & 2002 & 2003 \\
\hline $\begin{array}{l}\text { BRMA with harvest and } \\
\text { positive } \\
\text { profit per capita }\end{array}$ & $\begin{array}{l}\text { Maule } \\
\text { San Vicente } \\
\text { Dichato } \\
\text { Rumena }\end{array}$ & $\begin{array}{l}\text { Maule } \\
\text { San Vicente } \\
\text { Dichato } \\
\text { Puerto Yana } \\
\text { Rumena } \\
\text { Candelarias Canteras } \\
\text { Perone } \\
\text { Chome } \\
\text { Los Piures } \\
\text { Puerto Norte A } \\
\text { Puerto Norte B } \\
\text { Puerto Norte C }\end{array}$ & $\begin{array}{l}\text { Maule } \\
\text { San Vicente } \\
\text { Dichato } \\
\text { Puerto Yana } \\
\text { Rumena } \\
\text { Candelarias Canteras } \\
\text { Perone } \\
\text { Chome } \\
\text { Los Piures } \\
\text { Puerto Norte A } \\
\text { Puerto Norte B } \\
\text { Puerto Norte C } \\
\text { Punta Lavapié } \\
\text { Punta Los Piures } \\
\text { Bajo Rumena } \\
\text { Punta Raimenco } \\
\text { Punta Elisa } \\
\text { Puerto Sur Isla Santa María }\end{array}$ \\
\hline Sub total & 4 & 12 & 18 \\
\hline $\begin{array}{l}\text { BRMA with harvest and } \\
\text { negative } \\
\text { profit per capita }\end{array}$ & & & Sur Roca blanca \\
\hline Sub total & 0 & 0 & 1 \\
\hline $\begin{array}{l}\text { BRMA without harvest } \\
\text { and } \\
\text { profit per capita equal to } \\
\text { zero }\end{array}$ & $\begin{array}{l}\text { Coliumo Sector B } \\
\text { Tomé-Quichiuto } \\
\text { Punta Lirquén }\end{array}$ & Cerro Verde & \\
\hline Sub total & 3 & 1 & 0 \\
\hline $\begin{array}{l}\text { BRMA without harvest } \\
\text { and negative } \\
\text { profit per capita }\end{array}$ & Boca Sur & $\begin{array}{l}\text { Boca Sur } \\
\text { Coholgue } \\
\text { Coliumo Sector B } \\
\text { Tomé-Quichiuto }\end{array}$ & $\begin{array}{l}\text { Cocholgue } \\
\text { Cerro Verde }\end{array}$ \\
\hline Sub total & 1 & 4 & 2 \\
\hline TOTAL per year & 8 & 17 & 21 \\
\hline
\end{tabular}

Source: Servicio Nacional de Pesca.

The per capita profits correspond to 34 cases in areas with loco harvests and positive profits and one case of an area reporting loco harvests and a per capita profit less than zero (Table 2). For those areas reporting harvests, an average per capita profit of $\mathrm{M} \$$ 202 per year was observed with a standard deviation of M\$173. Eight of the BRMAs not reporting loco harvests present negative per capita profits and four present per capita profits equal to zero. In total, 35 data were analyzed from harvested areas and 11 from non-harvested areas.
Analysis of economic, environmental-biological, institutional-organizational, and the BRMA leader's characteristics in the Bío-Bío region

The average of the variables analyzed for every characteristic among the different years (2001-2003) according to the analysis of variance for one factor was statistically different in the variables PLOCO, FRACOMSIZE, NDIVERS, and URBAN (Table $3)$. In the other characteristics, it was not possible to reject the null hypothesis of equality between the means. For example, loco density between 2001 
Table 2. Profits observed in Bío-Bío region BRMA's from 2001 to 2003 by harvest situation.

\begin{tabular}{|c|c|c|c|c|c|}
\hline BRMA & $\begin{array}{c}\text { Case } \\
\text { numbers }\end{array}$ & $\begin{array}{c}\text { Mean } \\
\text { (thousands of \$) }\end{array}$ & $\begin{array}{l}\text { Standard } \\
\text { deviation }\end{array}$ & $\begin{array}{c}\text { Minimun } \\
\text { (thousands of \$) }\end{array}$ & $\begin{array}{c}\text { Maximun } \\
\text { (thousands of } \$ \text { ) }\end{array}$ \\
\hline $\begin{array}{l}\text { with harvest and } \\
\text { positive }\end{array}$ & & & & & \\
\hline $\begin{array}{l}\text { per capita profit } \\
\text { with harvest and } \\
\text { negative }\end{array}$ & 34 & 202.77 & 173.04 & 2.99 & 641.89 \\
\hline per capita profit & 1 & -150.59 & 0 & -150.59 & -150.59 \\
\hline $\begin{array}{l}\text { without harvest and } \\
\text { per capita profit } \\
\text { equal to zero }\end{array}$ & 4 & 0 & 0 & 0 & 0 \\
\hline $\begin{array}{l}\text { without harvest and } \\
\text { negative }\end{array}$ & & & & & \\
\hline per capita profit & 8 & -32.2 & 25.4 & -84.96 & -12.96 \\
\hline All data & 46 & 230.04 & 494.12 & -150.59 & 3087.38 \\
\hline
\end{tabular}

a: values deflated to 2001 values, according to the observed Consumer Price Index (IPC)

Table 3. Average annual figures for the variables analysed by characteristics in all Bío-Bío region BRMA's. SD: standard deviation.

\begin{tabular}{|c|c|c|c|c|c|c|c|c|}
\hline \multirow{2}{*}{ Type of factor } & \multirow{2}{*}{ Variable } & \multicolumn{2}{|c|}{2001} & \multicolumn{2}{|c|}{2002} & \multicolumn{3}{|c|}{2003} \\
\hline & & Average & SD & Average & SD & Average & SD & $\mathbf{F}^{\mathbf{a}}$ \\
\hline \multirow[t]{6}{*}{ Economic } & PLOCO & 790 & 141.8 & 1063.78 & 250.6 & 474.92 & 85.1 & $54.57 * * *$ \\
\hline & HAS & 105.4 & 67.27 & 135.34 & 119.6 & 143.54 & 163.3 & 0.23 \\
\hline & FRACOMSIZE & 24.20 & 26.33 & 39.52 & 27.5 & 53.6 & 20.4 & $4.58 * * *$ \\
\hline & SIZE & 73.35 & 32.74 & 85.8 & 24.9 & 94.34 & 22.8 & 2.04 \\
\hline & POLIGO & 337032.7 & 519917 & 274329.1 & 393718.7 & 268695.6 & 313387.6 & 0.10 \\
\hline & DENSRE & 0.5246 & 0.545 & 0.65429 & 0.6 & 0.965 & 0.7 & 1.67 \\
\hline \multirow{8}{*}{$\begin{array}{l}\text { Environmental } \\
\text { - Biological }\end{array}$} & DENSOTHER & 0.3816 & 0.63 & 8.34 & 32.3 & 8.19 & 34.9 & 0.21 \\
\hline & BETA & 2.765 & 1.13 & 2.898 & 0.8 & 3.008 & 0.7 & 0.28 \\
\hline & NMEMBERS & 43.6 & 20.85 & 48.7 & 25.7 & 46.57 & 23.5 & 0.13 \\
\hline & DIVERS & 30.25 & 22.76 & 34.29 & 18.6 & 53.9 & 23.2 & $5.49 * * *$ \\
\hline & MEN & 100 & 0 & 94.05 & 12.9 & 94.6 & 13.3 & 0.74 \\
\hline & FEE & 625 & 231.5 & 752.94 & 274.1 & 726.19 & 429.4 & 0.37 \\
\hline & UNION & 1 & 0 & 0.765 & 0.4 & 0.7619 & 0.4 & 1.16 \\
\hline & ASOCG & 0 & 0 & 0.24 & 0.4 & 0.19 & 0.4 & 1.06 \\
\hline \multirow{7}{*}{$\begin{array}{l}\text { Institutional- } \\
\text { Organizational }\end{array}$} & PATROL & 0.875 & 0.354 & 0.941 & 0.2 & 0.953 & 0.2 & 0.28 \\
\hline & URBAN & 0.75 & 0.46 & 0.353 & 0.5 & 0.238 & 0.4 & $3.57 * *$ \\
\hline & AGE & 46.875 & 11.43 & 47.3 & 11 & 45.4 & 11.1 & 0.15 \\
\hline & MARRIED & 0.875 & 0.353 & 0.882 & 0.3 & 0.714 & 0.5 & 0.97 \\
\hline & EDUCA & 2.75 & 1.035 & 2.17 & 1.4 & 2.14 & 1.3 & 0.71 \\
\hline & EXPLEADER & 5.125 & 4.67 & 5.41 & 3.8 & 6.19 & 4.4 & 0.25 \\
\hline & EXPFISHING & 26.25 & 8.41 & 30.11 & 10,6 & 28.67 & 10.2 & 0.40 \\
\hline Leader & OTHERACT & 0.5 & 0.53 & 0.353 & 0.50 & 0.19 & 0.4 & 1.46 \\
\hline
\end{tabular}

a: indicates that the null hypothesis of equality of means is rejected at significance levels of *** $1 \%, * * 5 \%, * 10 \%$. 
and 2003 fluctuated between 0.526 and 0.925 . The variable NMEMBERS was also observed, with an average of 43 to 50 members in the BRMAs per year analyzed.

Harvest activity profile of the BRMAs according to their characteristics

Considering that all the areas included in the study have Use Agreements and, therefore, could harvest, we decided to explore differences between the BRMAs according to their harvest activity. When we analyzed the group of managed areas reporting loco harvests in the study period and, separately, the group of managed areas that did not report loco harvests, we observed 35 data (Table 2). In this group, we found variables associated with the environmental-biological characteristics that are, on average, higher if the areas that did not report harvests are considered (Table 4). For the loco's price charac-

Table 4. Average figures of the characteristics of BRMA's of the Bío-Bío region with and without harvest reports in the period 2001-2003. SD: standard deviation.

\begin{tabular}{|c|c|c|c|c|c|c|c|c|c|c|}
\hline \multirow{2}{*}{$\begin{array}{l}\text { Type of } \\
\text { factor }\end{array}$} & \multirow[b]{2}{*}{ Variable } & \multicolumn{4}{|c|}{ BRMA with harvest $(n=35)$} & \multicolumn{4}{|c|}{ BRMA without harvest (n=11) } & \multirow[b]{2}{*}{$\mathbf{t}$} \\
\hline & & Mean & SD & $\begin{array}{c}\text { Mini- } \\
\text { mun }\end{array}$ & Maximun & Mean & SD & $\begin{array}{c}\text { Mini- } \\
\text { mun }\end{array}$ & $\begin{array}{c}\text { Maxi- } \\
\text { mun }\end{array}$ & \\
\hline Economic & PLOCO & 709.25 & 337.4 & 337 & 1318 & 968.45 & 220.24 & 514 & 1073 & $*$ \\
\hline \multirow{7}{*}{$\begin{array}{l}\text { Environ- } \\
\text { mental } \\
\text { - Biological }\end{array}$} & HAS & 148.3 & 147.46 & 11.68 & 658.7 & 88 & 56.96 & 19.07 & 166.7 & $* *$ \\
\hline & $\begin{array}{l}\text { FRA- } \\
\text { COM- } \\
\text { SIZE }\end{array}$ & 54.83 & 17.57 & 18.9 & 87.7 & 6.53 & 7.8 & 0 & 19.2 & $* * *$ \\
\hline & SIZE & 97.9 & 7.9 & 74.3 & 108.5 & 54.6 & 35.5 & 0 & 83.3 & $* * *$ \\
\hline & POLIGO & 362164.34 & 399771.2 & 14400 & 1387537 & 29701 & 25895.2 & 0 & 70600 & $* * *$ \\
\hline & DENSRE & 0.95 & 0.686 & 0.13 & 3.42 & 0.2 & 0.18 & 0 & 0.44 & $* * *$ \\
\hline & $\begin{array}{l}\text { DENSO- } \\
\text { THER }\end{array}$ & 88 & 34.7 & 0 & 160.56 & 0.643 & 0.634 & 0 & 1.65 & \\
\hline & BETA & 3.13 & 0.138 & 2.9 & 3.54 & 2.29 & 1.49 & 0 & 3.58 & $* * *$ \\
\hline \multirow{8}{*}{$\begin{array}{l}\text { Institution- } \\
\text { al- Organi- } \\
\text { zational }\end{array}$} & $\begin{array}{l}\text { NMEM- } \\
\text { BERS }\end{array}$ & 49.7 & 25.41 & 16 & 115 & 37.81 & 12.86 & 16 & 51 & \\
\hline & DIVERS & 51.1 & 19.04 & 11 & 86 & 15.18 & 13.49 & 0 & 32 & $* * *$ \\
\hline & MEN & 93.88 & 13.37 & 57 & 100 & 100 & 0 & 100 & 100 & \\
\hline & FEE & 758.6 & 372.3 & 250 & 2000 & 590.9 & 202.26 & 500 & 1000 & \\
\hline & UNION & 0.74 & 0.44 & 0 & 1 & 1 & 0 & 1 & 1 & $*$ \\
\hline & ASOCG & 0.22 & 0.43 & 0 & 1 & 0 & 0 & 0 & 0 & $*$ \\
\hline & PATROL & 097 & 0.17 & 0 & 1 & 0.82 & 0.4 & 0 & 1 & $*$ \\
\hline & URBAN & 0.29 & 0.46 & 0 & 1 & 0.64 & 0.5 & 0 & 1 & $*$ \\
\hline \multirow{6}{*}{ Leader } & AGE & 49.97 & 11.74 & 30 & 71 & 544.4 & 7.67 & 33 & 53 & \\
\hline & $\begin{array}{l}\text { MAR- } \\
\text { RIED }\end{array}$ & 0.8 & 0.4 & 0 & 1 & 0.82 & 0.4 & 0 & 1 & \\
\hline & EDUCA & 2.26 & 1.31 & 1 & 5 & 2.27 & 1.19 & 1 & 4 & \\
\hline & $\begin{array}{l}\text { EX- } \\
\text { PLEAD- } \\
\text { ER }\end{array}$ & 5.94 & 4.18 & 1 & 15 & 5 & 4.22 & 1 & 14 & \\
\hline & $\begin{array}{l}\text { EXP- } \\
\text { FISHING }\end{array}$ & 27.8 & 10.38 & 11 & 54 & 31.8 & 8.18 & 19 & 43 & \\
\hline & $\begin{array}{l}\text { OTHER- } \\
\text { ACT }\end{array}$ & 0.297 & 0.463 & 0 & 1 & 0.45 & 0.52 & 0 & 1 & \\
\hline
\end{tabular}

${ }^{\mathrm{a}}$ : indicates that the null hypothesis of equality of means is rejected at significance levels of *** $1 \%, * * 5 \%, * 10 \%$. 
teristic, we specifically observed differences among the values reported by the areas with and without harvests. The environmental-biological characteristics reflected in the variables HAS (hectares of the area), FRACOMSIZE (commercial size fraction), SIZE (average size), POLIGO (inhabitable polygon), DENSRE (loco density), and BETA (loco growth parameter) are significantly different between the areas with and without harvests. The areas with harvests are expected to have biological parameters suitable for an exploitable resource, which must necessarily be complemented with management capacities. If the institutional-organizational characteristics are considered (Table 4), we can see that areas with harvests are only similar to those without harvests in the number of members (NMEMBERS), percentage of men (MEN), and social quota (FEE), and that they differ significantly in the rest of the observed variables, such as the number of divers. Nonetheless, no important differences were observed regarding the organizational leader's characteristics with respect to the average of all the data observed.

It is possible to state that BRMAs with harvests have, on average, different institutional-organizational characteristics than those without harvests. This is reflected in the differences among the average values between areas with and without harvests with a significance level of $90 \%$ in the variables UNION, ASOCG, PATROL, and URBAN, and $99 \%$ in the variable NDIVERS. With regard to leadership, both groups have practically the same characteristics.

When analyzing only those managed areas with harvests and verifying whether there are differences among the variables for each year and in each characteristic, it is possible to indicate that the price of the species was significantly different among the years analyzed, increasing at the beginning of the study and decreasing later (Table 5). Likewise, an increment was registered in the hectares of the areas between the years, and differences were detected in the loco growth parameter (BETA) between the years analyzed. The institutional-organizational variables did not change over the years and failed to show any clear tendency, as was the case of the leader's characteristics.

To contrast with the previous analysis, we studied managed areas in the Bío-Bío region with Use Agreements between 2001 and 2003 without harvests (Table 6). In this group, the variables MEN, UNION, ASOCG were similar for all the years analyzed. The environmental-biological variables are higher, on average, in the areas with harvests than in those without harvests. In regard to the institutional-organizational characteristics, the number of members (NMEMBERS), of divers (NDIVERS), social quota (FEE), and vigilance (PATROL) were higher on average in the areas with than without harvests. The same was not true for the URBAN category, which was higher in the areas without harvests.

In this group of managed areas without loco harvests, the leadership characteristics are similar to those of the groups with harvests. However, the maximum value for the level of education present in the areas with harvests was higher than in those without harvests (the value equal to 5 indicates higher education).

Summarized briefly, the descriptive analysis suggests that the areas with harvests presented better environmental-biological characteristics than the areas without harvests. This could be observed in the high densities and growth parameters of the locos, which favored higher growth rates of the resource. Besides, the managed areas with harvests are administered by organizations composed of fishermen-divers, a characteristic that results in support for the task of resource harvesting.

\section{Economic performance profile of the BRMAs with harvests}

The economic performance of the Bío-Bío region BRMAs analyzed between 2001 and 2003 presented some tendencies according to their corresponding characteristics. The variables associated with the characteristics observed were analyzed, and some key variables were detected that would determine the economic performance in the managed areas reporting harvests. In the economic characteristics, we could descriptively observe a positive tendency in the per capita quasi rent of the variable PLOCO (price of the loco resource) as the value of the species price increased (Fig. 1).

Of the environmental-biological characteristics, loco density is expected to be a key variable in economic performance. This variable is directly related to the BRMA production capacity, which would determine the final harvest (Fig. 2). The analysis suggests an inverse relationship between the level of per capita profit and resource density. The latter indicates that a higher abundance of the resource in the management area would not necessarily result in greater per capita profits, which leads us to think 
Table 5. Average annual figures for the variables analysed by characteristics in the BRMA's of the Bío-Bío region, with 'Loco' harvest. SD: standard deviation.

\begin{tabular}{|c|c|c|c|c|c|c|c|c|}
\hline \multirow[b]{2}{*}{ Type of factor } & \multirow[b]{2}{*}{ Variable } & \multicolumn{2}{|c|}{2001} & \multicolumn{2}{|c|}{2002} & \multicolumn{2}{|c|}{2003} & \multirow[b]{2}{*}{$\mathbf{F}$} \\
\hline & & Average & SD & Average & SD & Average & SD & \\
\hline \multirow[t]{7}{*}{ Economic } & PLOCO & 789.8 & 216.7 & 1060 & 302.2 & 470.8 & 88.6 & $* * *$ \\
\hline & HAS & 122.14 & 73.96 & 153.6 & 134.8 & 150.45 & 169.9 & $*$ \\
\hline & FRACOM- & & & & & & & \\
\hline & SIZE & 44.04 & 22.88 & 53.05 & 19.91 & 58.21 & 14.62 & \\
\hline & SIZE & 94.4 & 7.67 & 95.36 & 10.44 & 100.2 & 5.38 & \\
\hline & POLIGO & 643884.25 & 615410.28 & 375019.9 & 433139.3 & 294735.6 & 318682.2 & \\
\hline & DENSRE & 0.849 & 0.626 & 0.8369 & 0.665 & 1.045 & 0.73 & \\
\hline \multirow{8}{*}{$\begin{array}{l}\text { Environmental } \\
\text { - Biological }\end{array}$} & $\begin{array}{l}\text { DENSO- } \\
\text { THER }\end{array}$ & 0.36 & 0.53 & 11.47 & 38.47 & 8.98 & 36.7 & \\
\hline & BETA & 3.13 & 0.10 & 3.052 & 0.1277 & 3.17 & 0.14 & $*$ \\
\hline & $\begin{array}{l}\text { NMEM- } \\
\text { BERS }\end{array}$ & 50.25 & 26.84 & 53.91 & 27.8 & 46.8 & 24.6 & \\
\hline & DIVERS & 49.25 & 7.54 & 42.33 & 13.45 & 57.1 & 21.79 & \\
\hline & MEN & 100 & 0 & 91.58 & 14.78 & 94.05 & 13.8 & \\
\hline & FEE & 750 & 288.7 & 816.7 & 275.8 & 723.7 & 444.8 & \\
\hline & UNION & 1 & 0 & 0.667 & 0.5 & 0.737 & 0.45 & \\
\hline & ASOCG & 0 & 0 & 0.33 & 0.49 & 0.21 & 0.42 & \\
\hline Institutional- & PATROL & 1 & 0 & 1 & 0 & 0.95 & 0.23 & \\
\hline \multirow[t]{7}{*}{ Organizational } & URBAN & 0.75 & 0.5 & 0.25 & 0.45 & 0.21 & 0.42 & $*$ \\
\hline & AGE & 48.5 & 15.06 & 48.5 & 11.9 & 45.63 & 11.5 & \\
\hline & MARRIED & 0.75 & 0.5 & 0.92 & 0.289 & 0.737 & 0.45 & \\
\hline & EDUCA & 2.5 & 1.29 & 2.2 & 1.47 & 2.26 & 1.3 & \\
\hline & $\begin{array}{l}\text { EXPLEAD- } \\
\text { ER }\end{array}$ & 4 & 2.58 & 5.9 & 4.03 & 6.4 & 4.57 & \\
\hline & $\begin{array}{l}\text { EXPFISH- } \\
\text { ING }\end{array}$ & 22 & 5.23 & 29.3 & 11.5 & 28.2 & 10.5 & \\
\hline & $\begin{array}{l}\text { OTHER- } \\
\text { ACT }\end{array}$ & 0.5 & 0.577 & 0.33 & 0.5 & 0.16 & 0.44 & \\
\hline
\end{tabular}

a: indicates that the null hypothesis of equality of means is rejected at significance levels of *** $1 \%, * * 5 \%, * 10 \%$.

that there are other characteristics - not necessarily environmental - that would explain the economic performance of an BRMA.

Another variable found to be critical for the economic performance was the surface that could be inhabited by the loco, which corresponded to the variable habitable polygon or suitable substrate for this species. In this case, a positive relationship between the surface of the managed area and the corresponding economic performance was observed (Fig. 3). The data suggest that the larger the surface suitable for loco growth, the bigger the per capita profits obtained.

Despite the previous results, when we contrasted the variable habitable polygon with loco density, we observed an inversely proportional relationship
(Fig. 4). This indicates that those managed areas with smaller habitable polygons presented a more aggregated resource than those areas with bigger habitable polygons. This suggests that abundances may be similar among the managed areas, but not necessarily equivalent to the obtained harvests. Thus, other characteristics must be affecting the harvest and, therefore, the economic performance of an BRMA.

\section{DISCUSSION}

The performance analysis for the considered 21 managed areas with Use Agreements in the Bío-Bío region between 2001 and 2003 showed an increment in the number of areas operating. Only one of the 
Table 6. Average annual figures for the variables analysed by characteristic in the BRMA's of the Bío-Bío region, without 'Loco' harvest. SD: standard deviation.

\begin{tabular}{|c|c|c|c|c|c|c|c|}
\hline \multirow[b]{2}{*}{ Type of Factor } & \multirow[b]{2}{*}{ Variable } & \multicolumn{2}{|c|}{2001} & \multicolumn{2}{|c|}{2002} & \multicolumn{2}{|c|}{2003} \\
\hline & & Average & SD & Average & SD & Average & SD \\
\hline Economic & PLOCO & 790 & 0 & 1073 & 0 & 514 & 0 \\
\hline \multirow{7}{*}{$\begin{array}{l}\text { Environmental } \\
\text { - Biological }\end{array}$} & HAS & 88.68 & 65.91 & 91.5 & 61.94 & 77.9 & 61.6 \\
\hline & $\begin{array}{l}\text { FRACOM- } \\
\text { SIZE }\end{array}$ & 4.37 & 6.72 & 7.03 & 7.89 & 9.6 & 13.6 \\
\hline & SIZE & 52.27 & 35.5 & 62.87 & 35.3 & 38.7 & 54.7 \\
\hline & POLIGO & 30181.18 & 30241.35 & 32671.14 & 26775.06 & 21315.5 & 30144.7 \\
\hline & DENSRE & 0.2 & 0.15 & 0.216 & 0.20 & 0.21 & 0.29 \\
\hline & $\begin{array}{l}\text { DENSO- } \\
\text { THER }\end{array}$ & 0.40 & 0.805 & 0.8168 & 0.60 & 0.69 & 0.453 \\
\hline & BETA & 2.39 & 1.62 & 3.255 & 1.436 & 1.47 & 2.08 \\
\hline \multirow{8}{*}{$\begin{array}{l}\text { Institutional- } \\
\text { Organizational }\end{array}$} & $\begin{array}{l}\text { NMEM- } \\
\text { BERS }\end{array}$ & 37 & 13.3 & 36.2 & 15.25 & 43.5 & 10.6 \\
\hline & DIVERS & 11.25 & 13.74 & 15 & 15.06 & 23.5 & 12.03 \\
\hline & MEN & 100 & 0 & 100 & 0 & 100 & 0 \\
\hline & FEE & 500 & 0 & 600 & 223.6 & 750 & 353.6 \\
\hline & UNION & 1 & 0 & 1 & 0 & 1 & 0 \\
\hline & ASOCG & 0 & 0 & 0 & 0 & 0 & 0 \\
\hline & PATROL & 0.75 & 0.5 & 0.8 & 0.44 & 1 & 0 \\
\hline & URBAN & 0.75 & 0.5 & 0.6 & 0.547 & 0.5 & 0.7 \\
\hline \multirow[b]{6}{*}{ Leader } & AGE & 45.25 & 8.42 & 44.2 & 8.61 & 43 & 8.49 \\
\hline & MARRIED & 1 & 0 & 0.8 & 0.44 & 0.5 & 0.7 \\
\hline & EDUCA & 3 & 0.82 & 2.2 & 1.3 & 1 & 0 \\
\hline & $\begin{array}{l}\text { EXPLEAD- } \\
\text { ER }\end{array}$ & 6.25 & 6.4 & 4.2 & 3.36 & 4.5 & 0.7 \\
\hline & $\begin{array}{l}\text { EXPFISH- } \\
\text { ING }\end{array}$ & 30.5 & 9.47 & 32.2 & 9.03 & 33.5 & 7.8 \\
\hline & $\begin{array}{l}\text { OTHER- } \\
\text { ACT }\end{array}$ & 0.5 & 0.57 & 0.4 & 0.547 & 0 & 0.707 \\
\hline
\end{tabular}

areas with harvests reported losses, having higher costs for the operational year than income. However, we present results from managed areas with Use Agreements licensed to harvest loco that, because they do not harvest, report per capita profits less than or equal to zero. The areas with harvests were found to obtain increased per capita profits.

The characteristics observed in all the areas show a significant variation in the price of loco from 2001 to 2003. A positive evolution is observed in the environmental-biological characteristic, specifically in the commercial size fraction of loco (FRACOMSIZE). Likewise, differences in the institutional-organizational characteristics are detected, for example, in the number of divers in the area (NDIVERS) and whether or not the area is urban (URBAN).

When comparing the means of each characteristic between those areas with harvests and those without harvests, we found significant differences in the economic, environmental-biological, and institutionalorganizational characteristics.

In the environmental-biological characteristics, the total surface of the areas is different, as is the commercial size fraction, the average loco size, habitable polygon, resource density, and the loco growth parameter. A first analysis of these differences suggests that they define the differences in economic performance between the areas. Additionally, we observed that average density of other resources is higher in areas without harvests than in those with harvests. This characteristic could indicate the area's productivity level and, therefore, its characteristics in terms of quality of the area for the production of benthic resources, which is the main objective of the BRMAs.

The difference in the number of divers between 


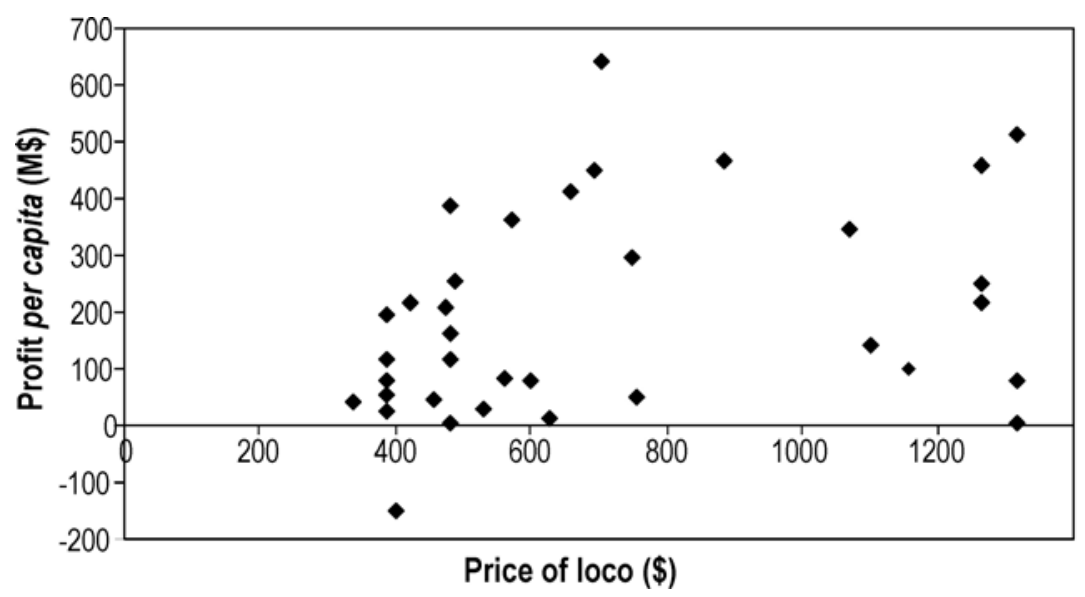

Figure 1. Relationship between the economic performance and the variable price of loco of the BRMA's with harvest in the Bío-Bío region (2001-2003).

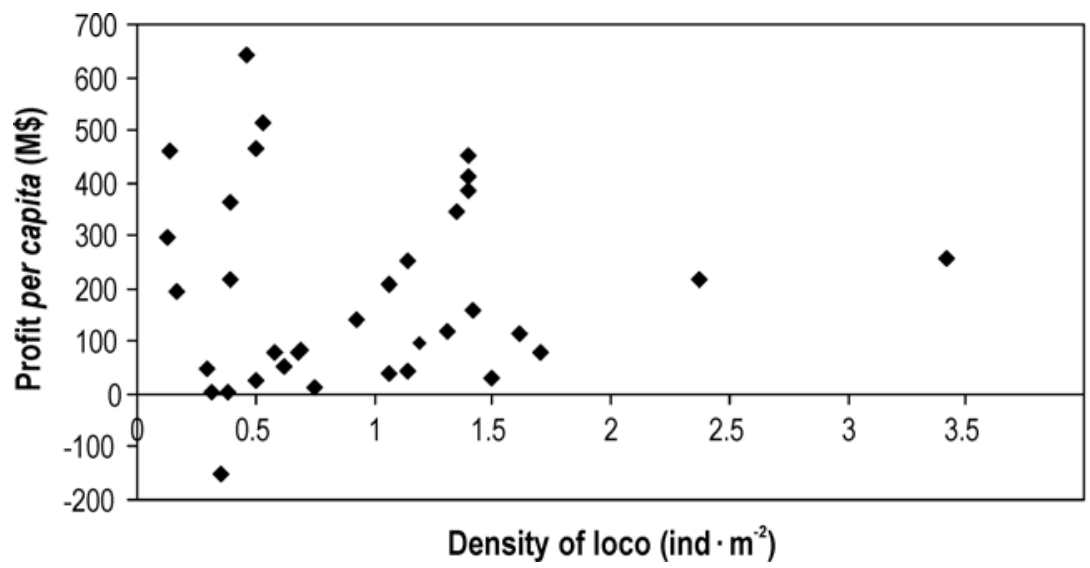

Figure 2. Relationship between the economic performance and the variable density of loco of the BRMA's with harvest in the Bío-Bío region (2001-2003).

these two areas is very important (with an error of $1 \%$ ), being higher in the areas with harvest. The presence of divers is necessary for the loco harvest itself and is fundamental for the activity as it is relevant in those areas with harvests. With an error of $10 \%$, differences are observed between the areas with labor or trade union associations, those having vigilance, and those in urban areas. In addition, the areas without harvests are all labor unions so, on average, they are also in urban areas unlike the areas with harvests, most of which are rural.

If we integrate the environmental-biological and institutional-organizational characteristics, we see that the areas with harvests are rural and have greater densities of loco and other resources than the areas without harvests, which are mostly urban and have low densities. This could indicate some environmental characteristics that favor loco production associated with areas of lesser contact with urban activity and directly related to the productivity conditions of the areas.

On one hand, for the areas with harvests, we observed significant changes in the price of loco between years. There are average changes in the hectares produced by the entry of new areas; this could also produce the variation in the growth parameter of the species. It is not possible to observe tendencies in the rest of the characteristics, of which only the urban areas show differences among the years. On the other hand, for the areas without loco harvests, we found that only the commercial size fraction, the number of divers in the organization, and the 


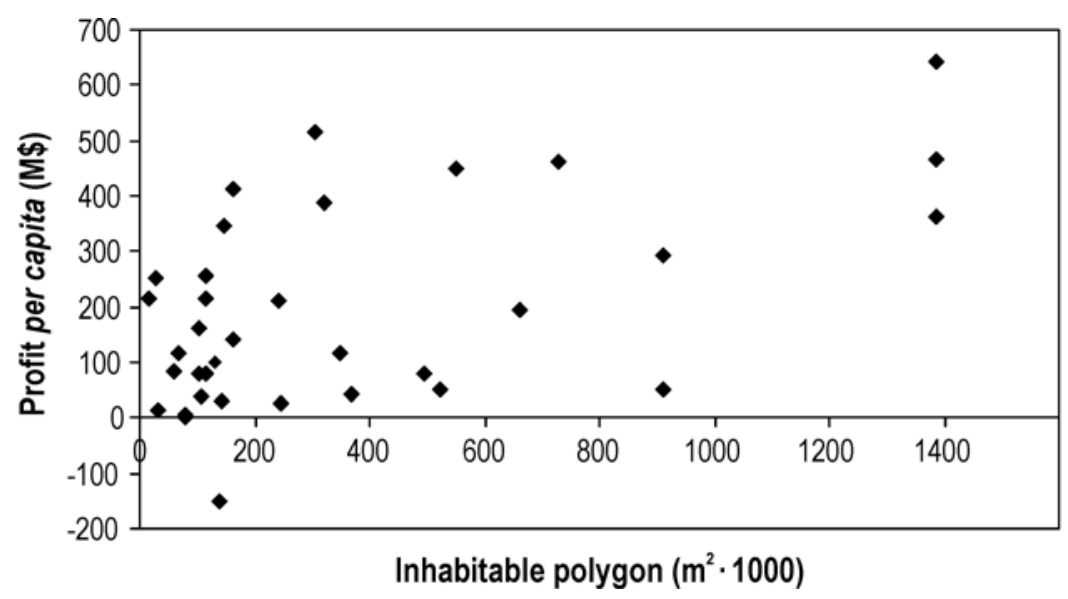

Figure 3. Relationship between the economic performance and the variable inhabited polygon of BRMA's with harvest in the Bío-Bío region (2001-2003).

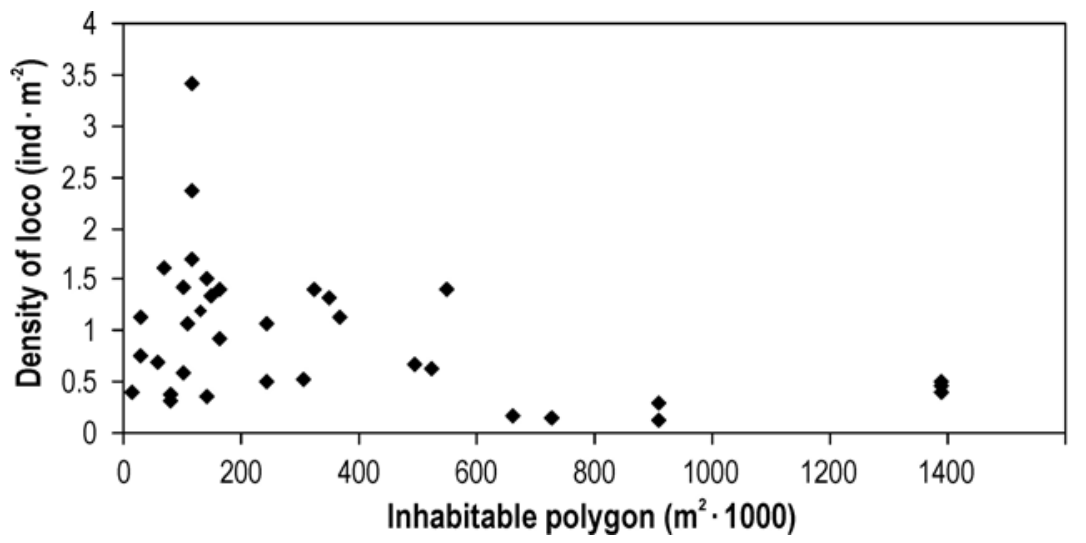

Figure 4. Relationship between the inhabited polygon and density of the resource loco of BRMA's with harvest in the Bío-Bío region (2001-2003).

social quota tended to increase. This indicates the incorporation, in the years analyzed, of other BRMAs with Use Agreements, and therefore authorized to harvest loco, which had distinct characteristics from the original ones. However, all these managed areas have been labor unions.

To summarize, it is possible to indicate that there are clear differences between the areas with and without harvests in the Bío-Bío region with regard to their environmental-biological and institutionalorganizational characteristics and without differences in the organizational leader's characteristics. This is important in order to define the characteristics of an BRMA that will have a positive economic performance allowing it to fulfil the objective of maintaining the viability of the artisanal economic activity through the designation of natural shoals of benthonic resources.

This is reflected in the tendencies of the per capita profit in the areas with harvests in relation to certain characteristics that are determinant for the economic performance. The variables price of the species and habitable polygon are positively related to the economic performance. The opposite is observed for the variable resource density, which must be analyzed considering the total extension of the management area because the larger the surface, the lower the density. Through this analysis, it is understood that abundance is the factor that will affect an area's economic performance. 


\section{ACKNOWLEDGEMENTS}

The authors are specially grateful to two anonymous referees of this journal for detailed and insightful comments and suggestions on a previous version of this article. Our colleagues Rosa Aguilera and Eugenio Bobenrieth also provided helpful comments and suggestions on early stages of this research. We gratefully acknowledge the partial financial support for this research provided by the Dirección de Investigación, Universidad Católica de la Santísima Concepción.

\section{REFERENCES}

Canavos, G.C. 1992. Probabilidad y estadística. Aplicaciones y métodos. McGraw-Hill, México, 651 pp.

Castilla, J.C. \& M. Fernández. 1998. Small-scale benthic fisheries in Chile: on comanagement and sustainable use of benthic invertebrates. Ecol. Appl., 8(Suppl.): S124-S132.

Cereceda, L. \& D. Czischke. 2001. Nueva modalidad institucional para el desarrollo sustentable del sector pesquero artesanal. Rev. Ambiente y Desarrollo, 17(2): 40-49.

Stotz, W., L. Caillaux, D. Lancellotti, J. Aburto, M. Valdebenito, C. Cerda, R. Varela, P. Araya \& L. Rodríguez. 2005. Formulación de metodologías para evaluar el desempeño de áreas de manejo. Informe Final Proyecto FIP 2003-18, Grupo de Ecología y Manejo de Recursos, Facultad de Ciencias del Mar, Universidad Católica del Norte, Coquimbo, $257 \mathrm{pp}$.

González, E. 1996. Thalassorama: territorial use rights in chilean fisheries. Mar. Resour. Econ., 11(3): 211-218.

Jerez, G. 2001. El concepto de área de manejo como base para la conservación de los recursos bentónicos y su aporte a la biodiversidad marina costera chilena. In: K. Alveal \& A. Antezana (eds.). Sustentabilidad de la biodiversidad. Un problema actual. Bases científico-técnicas, teorizaciones y proyecciones. Universidad de Concepción, Concepción, pp. 855-868.

Received: 8 July 2005; Accepted: 16 October 2007
Kamara, A., B. Van Koppen \& L. Magingxa. 2002. Economic viability of small-scale irrigation systems in the context of state withdrawal: the Arabie scheme in the Northern Province of South Africa. Elsevier Science, Physics and Chemistry of the Earth, 27: 815-823.

Ostrom, E. \& R. Gardner. 1993. Coping with asymmetries in the commons: self-governing irrigation systems can work. J. Econ. Perspect., 7(4): 93-112.

Ostrom, E. 1995. Designing complexity to govern complexity. In: S. Hanna \& M. Munasinghe (eds.). Property rights and the environment: social and ecological issues. The Beijer International Institute of Ecololgical Economics and the World Bank, Washington, DC, pp. 33-45.

Palma, M. \& C. Chávez. 2006. Normas y cumplimiento en Áreas de Manejo de Recursos Bentónicos. Estudio de caso en la región del Bío-Bío. Estudios Públicos, 103(Invierno 2006): 237-276.

Pollnac, R.B., B.R. Crawford \& M.L. Gorospe. 2001. Discovering factors that influence the success of community-based marine protected areas in the Visayas, Philippines. Coastal Management Report \#2229. PCAMRD Book Series No. 33. Coastal Resources Center, University of Rhode Island, Narragansett, RI, USA, and Philippine Council for Aquatic and Marine research and Development, Los Banos, Laguna, Phillines. 33 pp. www.crc.uri.edu/ download/VIS_004F.PDF. Revised: 1 April 2005.

Subsecretaría de Pesca (SUBPESCA). 1995. Reglamento sobre Áreas de Manejo y Explotación de Recursos Bentónicos $\mathrm{N}^{\circ} 355$. Ministerio de Economía Fomento y Reconstrucción, 16 pp. http://www.subpesca.cl/template/tablas_chicas/04. asp?idseccion=256. Revised: 4 February 2005.

Sumalde, Z. \& S. Pedroso. 2001. Transaction costs of a community based coastal resource management program in San Miguel Bay, Philippines. Departament of Economics, College of Economics and Management, University of Philippines, $70 \mathrm{pp}$.

Taylor, M. 1987. The possibility of cooperation. In: J. Elster \& G. Hernes (eds.). Studies in rationality and social change. Cambridge University Press, Cambridge, 205 pp. 